\title{
Presence of Delphinus capensis and Delphinus delphis (Cetacea: Delphinidae) in Uruguay
}

\author{
EDUARDO JURI ${ }^{1}$, MEICA VALDIVIA ${ }^{1}$ AND ALFREDO LE BAS ${ }^{1,2}$ \\ ${ }^{1}$ Laboratorio de Mamíferos Marinos, Museo Nacional de Historia Natural, 25 de Mayo 582, CP 11100, Montevideo, Uruguay, \\ ${ }^{2}$ Sección Fisiología y Nutrición, Facultad de Ciencias, Universidad de la República, Iguá 4225, 11400, Montevideo, Uruguay
}

\begin{abstract}
The taxonomy and distribution patterns of the common dolphins (genus Delphinus) are problematic among cetaceans and particularly complicated in the south-western Atlantic Ocean. On the basis of national collections, we found ten adult skulls of the genus Delphinus of Uruguayan origin. The two currently recognized species for the genus were identified based on craniometric measurements: the pelagic short beaked form (Delphinus delphis, $N=3$ ) and the coastal long beaked form (Delphinus capensis, $N=4$ ), although previous studies only recognized D. capensis for Uruguay. Three specimens could not be identified (Delphinus sp.) because of broken skull (2) and intermediate measures (1). This result is consistent with a recent review on the biogeography of the genus in the south-western Atlantic Ocean.
\end{abstract}

Keywords: Atlantic Ocean, Cetacea, Delphinidae, common dolphins, distribution

Submitted 26 September 2010; accepted 9 February 2011

\section{INTRDDUCTION}

The populations of the genus Delphinus are distributed in tropical, subtropical and temperate waters worldwide (Jefferson et al., 1993) and show a high degree of morphological variation. Their taxonomy has undergone numerous revisions, with at least 30 nominal species described for the genus (Hershkovitz, 1966). Genetic (Rosel et al., 1994) and morphological (Heyning \& Perrin, 1994) evidence for the existence of two species of common dolphins: a short beaked form (Delphinus delphis Linnaeus, 1758) and a long beaked one (Delphinus capensis Gray, 1828) was found in the northeastern Pacific populations. Heyning \& Perrin (1994) also proposed wide global distributions for both species. However, genetic (Natoli et al., 2006) and morphological (Bell et al., 2002; Murphy et al., 2006; Tavares, 2006; Westgate, 2007) studies are not consistent with the conclusions of Heyning \& Perrin (1994).

Natoli et al. (2006) found that the oceanic short beaked form (D. delphis) is a well-defined species, contrary to the coastal long beaked form (D. capensis sensu Heyning \& Perrin, 1994), which suggests that different populations may have evolved independently converging in the same morphotype.

While the taxonomic status of the south-western Atlantic population(s) of the long beaked morphotype is not clearly established, we will refer to it as Delphinus capensis, following the current diagnostic criteria used by Heyning \& Perrin (1994) to distinguish $D$. capensis from $D$. delphis.

Corresponding author:

E. Juri

Email: edujuri@gmail.com
In the south-western Atlantic Ocean, D. delphis has been cited for Argentinean waters (Crespo et al., 2000; Bastida \& Rodríguez, 2006) and D. capensis for southern and southeastern Brazilian waters: São Paulo, Paraná and Santa Catarina States (Santos et al., 2002; Cherem et al., 2004; Zerbini et al., 2004). Moreover, Martins et al. (1995) reported a stranded D. delphis at the southernmost State of Rio Grande do Sul (Brazil).

Tavares et al. (2010) reviewed the biogeography of the genus Delphinus in the south-western Atlantic Ocean and proposed three stocks: one located in northern Brazil (Pará State, Stock 1: $0-1^{\circ} \mathrm{S}$ ) and two from south-eastern Brazil (Rio de Janeiro $\approx 22^{\circ} \mathrm{S}$ ) to central Argentina (Patagonia $\approx$ $42^{\circ} \mathrm{S}$ ). These authors found two distinct patterns in habitat use stratified by water depth: in south-eastern Brazil (from $22^{\circ} \mathrm{S}$ to $28^{\circ} \mathrm{S}$, Stock 2) sightings were restricted to coastal waters with depths ranging from 18 to $70 \mathrm{~m}$, which is similar to the reported habitat for $D$. capensis in other parts of the world. On the other hand, in the area that extends from southern Brazil to central Argentina (from $28^{\circ} \mathrm{S}$ to $42^{\circ} \mathrm{S}$ ), sightings were recorded in deeper waters, ranging from 71 to $1435 \mathrm{~m}$ (Stock 3), which resembles the pattern observed for D. delphis (see Figure 1). According to Tavares et al. (2010), Stocks 2 and 3 include both forms (D. delphis and D. capensis) sensu Heyning \& Perrin (1994).

Early Uruguayan mammals' lists cited D. microps (Arechavaleta, 1882; Figueira, 1894), a synonym of D. capensis (Heyning \& Perrin, 1994; Mead \& Brownell, 2005). Ximénez et al. (1972) and Pilleri (1977) replaced that name by D. delphis. González (2001) returned to D. capensis based on Heyning \& Perrin's propositions (1994). However, these last authors did not directly examine the south-western Atlantic specimens. Their results were only based on the craniometric measurements published by Casinos (1984) of three 


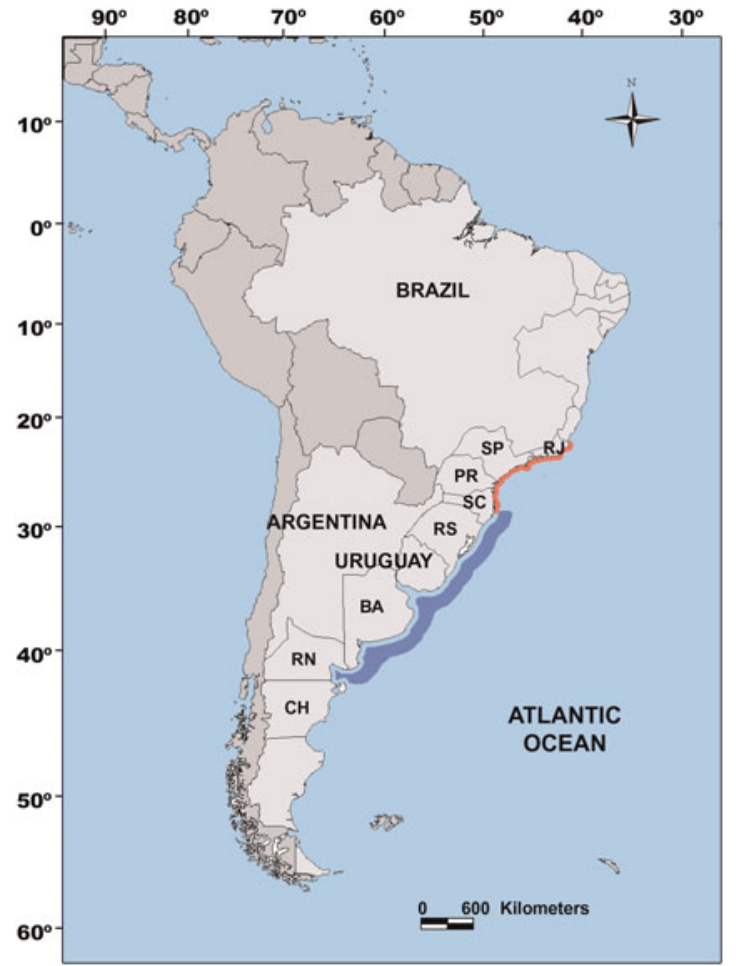

Fig. 1. Proposed scheme of distribution of Stock 2 and Stock 3 of common dolphins in south-western Atlantic waters (Tavares et al., 2010). Red patch, Stock 2; blue patch, Stock 3. States of Brazil: RJ, Rio de Janeiro; SP, São Paulo; PR, Paraná; SC, Santa Catarina; RS, Rio Grande do Sul. Provinces of Argentina: BA, Buenos Aires; RN, Río Negro; CH, Chubut.

specimens from Brazil, five from Argentina and two from Venezuela.

In a recent revision, Tavares et al. (2010) only found D. capensis in Uruguay $\left(\approx 34^{\circ} \mathrm{S}\right)$ based on the examination of three skulls. According to the same author, there were very few records and little information was available in the scientific collections visited.

The oceanographic dynamics must be taken into account if we deal with cetacean distributions. The most relevant feature of the south-western Atlantic waters is the Subtropical Convergence (SC): cold sub-Antarctic waters from the Malvinas/Falkland Current encounter warm waters of the Brazil Current (Seeliger et al., 1997). This system is dynamic throughout the year. During the austral winter, the Malvinas/ Falkland Current reaches lower latitudes, bathing the Uruguayan and Rio Grande do Sul State (southern Brazil) coasts. During the summer, the SC moves to the south, and the warmer Brazil Current washes the shores of Uruguay and Buenos Aires Province (Argentina) (Wainer et al., 2000).

The geographical closeness of the proposed stocks of Delphinus, the complex dynamics of the SC and the little information of the specific allocation of the specimens from Uruguay, lead to the question whether both forms of Delphinus occur in Uruguayan waters.

\section{MATERIALS AND METHDDS}

All available Uruguayan specimens of the genus Delphinus held in national collections were reviewed. Twelve skulls were examined, but only ten were included in the analysis because of the cranial maturity: MMPE 016 (Museo del Mar de Punta del Este); MNHN 5760, 5819, 5820, 6105, 6133 (Museo Nacional de Historia Natural); ZVCM 459, 1089, 2108 (Facultad de Ciencias, Universidad de la República) and DINARA w/n (Dirección Nacional de Recursos Acuáticos). As distal fusion is not an accurate marker of cranial maturity in D. delphis (Perrin \& Heyning, 1993), the specimens were identified as adults based on Tavares et al. (2010): 'fused and secure, closed sutures, closed alveoli, and distal fusion between the premaxillae and maxillae at the tip of the rostrum'. The cranial measurements were taken with a $0.1 \mathrm{~mm}$ precision calliper according to Perrin (1975). Each measurement was repeated three times in order to obtain mean values. The diagnostic tool to discriminate the short and long beaked forms was the rostral ratio (RR) criteria presented by Heyning \& Perrin (1994). The RR was calculated as the ratio of length of rostrum/zygomatic width (1.21-1.47 for Delphinus delphis and 1.52-1.77 for Delphinus capensis).

\section{RESULTS}

Four specimens were identified as Delphinus capensis, three as Delphinus delphis and three could not be determined (Delphinus sp.) because of broken beaks or intermediate value of RR (Table 1).

For the specimen MNHN 5819, the value of the RR lies between long and short beaked ranges and therefore is not useful to identify it at specific level. In the case of MNHN 5760 and MNHN 5820, the RR could not be calculated because of their broken beaks. As the coloration pattern and total length of the two forms may vary from the criteria presented by Heyning \& Perrin (1994), especially in the southwestern Atlantic (Tavares et al., 2010), these individuals were identified as Delphinus sp.

Despite the low number of specimens available, we found both forms of Delphinus in Uruguay.

\section{DISCUSSION}

The occurrence of both forms of Delphinus in Uruguayan waters does not indicate per se to which $\operatorname{stock}(\mathrm{s})$ they belong. Since Stock 2 does not reach latitudes higher than $28^{\circ} \mathrm{S}$ and the distribution of Stock 3 includes Uruguay (Tavares et al., 2010), we confirm the existence of $D$. capensis and report $D$. delphis, not already communicated for Uruguay.

Our result is consistent with the hypothesis that the occurrence of both forms of Delphinus in Uruguayan waters could be the result of displacements of Stock 3 of short and long beaked common dolphins, probably associated with the dynamics of the SC and storms. The scarcity of records for Uruguay is consistent with the fact that Stock 3 distributes in deeper waters, far from the coastline.

The existence of intermedial RR values between the two recognized species for the Uruguayan specimens was already found for other areas in the south-western Atlantic (Tavares et al., 2010), North Atlantic (Murphy et al., 2006; Westgate, 2007) and Australia (Bell et al., 2002). The presence of these intermedial values could respond to the fact that RR ranges proposed by Heyning \& Perrin (1994) may not apply exactly to the specimens of the south-western Atlantic (see discussion in Tavares et al., 2010). 


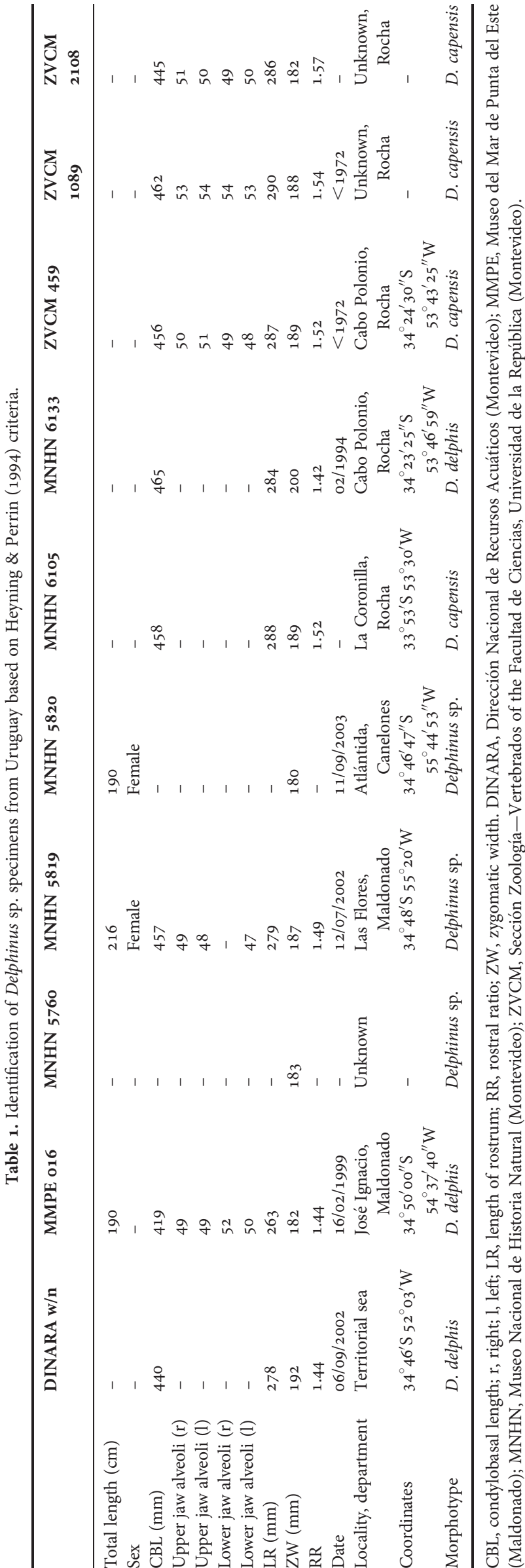

On the other hand, as our information comes mostly from strandings, it provides a lineal view of the population ranges. Despite the scarcity of data and lack of reported sightings, we can draw the following conclusion: the presence of both species in Uruguayan waters is confirmed. This finding is a relevant input for a re-examination of the current approach on the distribution of the genus Delphinus in the southwestern Atlantic.

\section{ACKNDWLEDGEMENTS}

We appreciate the cooperation shown by Maurício Tavares for the comments that helped to improve the manuscript. We are indebted to Julio Chocca, Bernardo González, Yamandú Marin and Gastón Beathyate (Laboratorio de Tecnología Pesquera, DINARA), Alberto Ponce de León and Cesar Barreiro (Departamento de Mamíferos Marinos, DINARA), Pablo Etchegaray (Museo del Mar of Punta del Este) and Melitta Meneghel (Facultad de Ciencias, Universidad de la República), who allowed us to examine skulls and catalogues; Enrique A. Crespo and Diego Rodríguez for literature support. This work would not have been possible without the permanent support and encouragement of Ricardo Praderi and Enrique M. González.

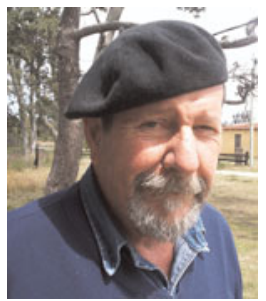

This contribution is dedicated to Ing. Agr. Ricardo Praderi, researcher at the Museo Nacional de Historia Natural of Montevideo. Pioneer in the cetacean studies in Uruguay, with more than 50 years dedicated to research, excellent professor and beloved friend.

\section{REFERENCES}

Arechavaleta J. (1882) Reino Animal. In Album de la República Oriental del Uruguay compuesto para la Exposición Continental de Buenos Aires. Montevideo, Uruguay, pp. 41-54.

Bastida R. and Rodríguez D. (2006) Orden Cetacea. In Barquez R.M., Díaz M.M. and Ojeda R.A. (eds) Mamíferos de Argentina. Sistemática y Distribución. Tucumán: Sociedad Argentina para el Estudio de los Mamíferos, pp. 122-144.

Bell C.H., Kemper C.M. and Conran J.G. (2002) Common dolphins Delphinus delphis in southern Australia: a morphometric study. Australian Mammalogy 24, 1-10.

Casinos A. (1984) A note on the common dolphin of the South American Atlantic coast with some remarks about speciation of the genus Delphinus. Acta Zoologica Fennica 172, 141-142.

Cherem J.J., Simões-Lopes P.C., Althoff S. and Graipel M.E. (2004) Lista dos mamíferos do Estado de Santa Catarina, sul do Brasil. Mastozoología Neotropical 11, 151-184.

Crespo E.A., Koen Alonso M., Dans S.L., García N.A., Pedraza S.N., Coscarella M.A. and González R. (2000) Incidental catch of dolphins in mid-water trawls for southern anchovy off Patagonia. Journal of Cetacean Research and Management 2, 11-16.

Figueira J.H. (1894) Contribución a la fauna uruguaya. Enumeración de mamíferos. Anales del Museo Nacional de Historia Natural de Montevideo 1, 187-217. 
González E.M. (2001) Guía de campo de los mamíferos de Uruguay. Introducción al estudio de los mamíferos. 1st edition. Montevideo: Vida Silvestre.

Hershkovitz P. (1966) Catalogue of living whales. United States National Museum Bulletin 246, 1-259.

Heyning J.E. and Perrin W.F. (1994) Evidence for two species of common dolphins (genus Delphinus) from the eastern North Pacific. Contributions in Science 442, 1-35.

Jefferson T.A., Leatherwood S. and Webber M.A. (1993) Marine mammals of the world. FAO species identification guide. 1st edition. Rome. United Nations Enviroment Programme.

Martins M.B., Ott P.H. and Danilewicz D.S. (1995) Notes on the common dolphins (genus Delphinus) from southern Brazil. Eleventh Biennial Conference on the Biology of Marine Mammals, 14-18 December 1995. Orlando, Florida, p. 73.

Mead J.G. and Brownell Jr R.L. (2005) Order Cetacea. In Wilson D.E. and Reeder D.M. (eds) Mammal species of the world. A taxonomic and geographic reference. Baltimore: Johns Hopkins University Press, pp. $723-743$.

Murphy S., Herman J.S., Pierce G.J., Rogan E. and Kitchener A.C. (2006) Taxonomic status and geographical cranial variation of common dolphins (Delphinus) in the eastern North Atlantic. Marine Mammal Science 22, 573-599.

Natoli A., Cañadas A., Peddemors V.M., Aguilar A., Vaquero C., Fernández-Piqueras P. and Hoelzel A.R. (2006) Phylogeography and alpha taxonomy of the common dolphin (Delphinus sp.). Journal of Evolutionary Biology 19, 943-954.

Perrin W.F. (1975) Variation of spotted and spinner porpoise (genus Stenella) in the eastern Pacific and Hawaii. Bulletin of the Scripps Institution of Oceanography of the University of California 21, 1-206.

Perrin W.F. and Heyning J.E. (1993) Rostral fusion as a criterion of cranial maturity in the common dolphin, Delphinus delphis. Marine Mammal Science 9, 195-197.

Pilleri G. (1977) Note on the geographic distribution of cetaceans in the Uruguayan coastal waters. Investigations on Cetacea 8, 89-94.

Rosel P.E., Dizon A.E. and Heyning J.E. (1994) Genetic analysis of sympatric morphotypes of common dolphins (genus Delphinus). Marine Biology 119, 159-167.
Santos M.C. de O., Rosso S. and Ramos R.M.A. (2002) Common dolphins (genus Delphinus) in south-eastern Brazil. Mammalian Biology $67,47-50$.

Seeliger U., Odebrecht C. and Castello J.P. (1997) Subtropical convergence environments-the coast and sea in the south-western Atlantic. Berlin: Springer-Verlag.

Tavares M. (2006) O gênero Delphinus Linnaeus, 1758 (Cetacea, Delphinidae) no litoral brasileiro: morfometria sincraniana, padrão de coloração e distribução. MSc thesis. Universidade Federal do Rio Grande do Sul, Porto Alegre, Brazil.

Tavares M., Moreno I.B., Siciliano S., Rodríguez D., Santos M.C. de O. and Fabián M.E. (2010) Biogeography of common dolphins (genus Delphinus) in the Southwestern Atlantic Ocean. Mammal Review 40, $40-64$.

Wainer I., Gent P. and Goni G. (2000) Annual cycle of the BrazilMalvinas confluence region in the National Center for Atmospheric Research Climate System Model. Journal of Geophysical Research $105,167-177$.

Westgate A.J. (2007) Geographic variation in cranial morphology of short-beaked common dolphins (Delphinus delphis) from the North Atlantic. Journal of Mammalogy 88, 678-688.

Ximénez A., Langguth A. and Praderi R. (1972) Lista sistemática de los mamíferos del Uruguay. Anales del Museo Nacional de Historia Natural de Montevideo 7, 1-49.

and

Zerbini A.N., Secchi E.R., Bassoi M., Dalla-Rosa L., Higa A., Sousa L., Moreno I.B., Moller L.M. and Caon G. (2004) Distribuição e abundância relativa de cetáceos na Zona Econômica Exclusiva na Região Sudeste-Sul do Brasil. Série Documentos Revizee-Score Sul. Instituto Oceanográfico, Universidade de São Paulo, 40 pp.

\section{Correspondence should be addressed to:}

E. Juri

Laboratorio de Mamíferos Marinos

Museo Nacional de Historia Natural

25 de Mayo 582

CP 11100, Montevideo

Uruguay

email: edujuri@gmail.com 